\title{
Transformative e-Learning and Teaching in Mandatory Tertiary Education
}

\author{
Dr Peter Keegan \\ Department of Ancient History, Faculty of Arts, Macquarie University \\ North Ryde NSW 2109, Australia \\ Tel: 61-2-9850-8819 E-mail: peter.keegan@mq.edu.au
}

Received: September 8, 2011

Accepted: October 11, $2011 \quad$ Published: November 1, 2011

doi:10.5539/ass.v7n11p66

URL: http://dx.doi.org/10.5539/ass.v7n11p66

\begin{abstract}
Previous research identifies as crucial to successful online learning and teaching (eLT) transformative pedagogical strategies. Transformative L \& T is the process by which we call into question our taken-for-granted habits of mind or mindsets to make them more inclusive, discriminating, open and reflective in order to guide our actions. This process can be codified into three phases that effectively 'close the L \& T loop': critical reflection (feedback), reflective discourse (evaluation), and action (learning and teaching quality). This paper will examine the validity of these elements of transformative learning in relation to a blended (on-campus/online) tertiary-level capstone unit and current pedagogical models of eLT. Identifying and analyzing transformative L \& T principles embedded (explicitly and implicitly) in the current blended experience provides a range of learning ideas, beliefs, habits and assumptions - pointing to self-direction, metacognition, and collaborative learning as key eLT facilitators - from which a broader pedagogical template responsive to eLT needs can be developed.
\end{abstract}

Keywords: Transformative learning, Online learning and teaching, Action learning, Collaborative learning, Critical reflection, Metacognition

\section{Background}

Since the establishment in 2010 of qualifying majors for the Bachelor of Arts and Bachelor of Ancient History (Honours) degrees at Macquarie University, the Department of Ancient History has offered two blended (on-campus/online) Capstone units: AHIS339 (Greece, Rome, Late Antiquity) and AHIS399 (Egypt and the Near East). In 2012 a dedicated Macquarie University Bachelor of Arts degree program will be offered exclusively online in partnership with Open Universities Australia via Moodle 2.1. For the first time, as part of this new program, distance education learners and teachers will experience online-exclusive delivery of a Capstone unit keyed to the social science and humanities disciplines (Critical and Cultural Studies; History and Politics; Philosophy; Society, Life and Learning), including a Capstone in Ancient History (AHIS390).

Preparing for the implementation and delivery of AHIS390 as an effective, pedagogically-sound online Capstone unit requires research into

- features of the existing Capstones which best provide an opportunity to assess what students have learnt in the Ancient History educational program and how effectively they can apply what they have learnt (Rowles et al, 2004).

- pedagogical frameworks which best support the design of AHIS390 both as an e-learning experience and as a culminating set of personal and academic experiences at the end of a program of study (Huber \& Hutchings, 2004; TLC, 2008).

Previous research identifies as crucial to successful online learning and teaching (eLT) transformative pedagogical strategies (Boyer, 2006). Transformative L \& T is the process by which we call into question our taken-for-granted habits of mind or mindsets to make them more inclusive, discriminating, open and reflective in order to guide our actions. As O'Sullivan and Morrell $(2002$, p.18) explain,

'Transformative learning involves experiencing a deep, structural shift in the basic premises of thought, feelings, and actions. It is a shift of consciousness that dramatically and irreversibly alters our way of being in the world. Such a shift involves our understanding of ourselves and our self-locations; our relationships with other humans 
and with the natural world; our understanding of relations of power in interlocking structures of class, race and gender; our body awarenesses, our visions of alternative approaches to living; and our sense of possibilities for social justice and peace and personal joy.'

This approach to $L \&$ T is not new. In the early 1900s, for example, the educational theorist John Dewey (1916) supported an approach to education that would transform schools, work organizations, and the society at large into more participative, democratic cultures (Gregson, 1995). Dickinson (1992, n.p.) stressed the importance of finding new ways of communicating and working together "to confront the problems that threaten the lives of human beings, countries, even the planet itself". Mezirow (2000, p.4) describes a learning process of "becoming critically aware of one's own tacit assumptions and expectations and those of others and assessing their relevance for making an interpretation." The attempted transition, however, is a relatively recent phenomenon in eLT (Raschke, 2003, p. 110).

While there has been some criticism of the emphasis given to rationality in transformative theory (Cranton 1994; Taylor 1998), the author is convinced that the modalities inherent in its application to L \& T are grounded in conditions of challenging and supporting social relations, of communicative opportunities, and of contexts of difference that present learners and teachers with the possibility of thinking otherwise (Burbules and Berk 1999). That said, transformative learning may be codified into three phases: critical reflection, reflective discourse, and action (Merriam et al, 2007, p.321). In this light, various studies point to self-direction, metacognition, and collaborative learning as key eLT facilitators (Heinecke, Dawson, Willis, 2001; Reushle, 2005; Taylor, 2007; Cranton, 2010). This paper assesses the validity of these elements of transformative learning in relation to the development of the OUA Ancient History Capstone Unit and current pedagogical models of eLT.

\section{The Ancient History Capstone Units}

In order to contextualize the applicability to AHIS390 of the feedback-evaluation-action nexus underpinning transformative $\mathrm{L} \& \mathrm{~T}$ perspectives, it is appropriate to outline the nature of the current blended Capstone units offered by the Department of Ancient History at Macquarie.

\subsection{Unit description}

The 12-week, 3 credit-point, 300-level (final year) Capstones are mandatory units designed around a set of topics relevant to each of the Ancient History Majors: Greece, Rome, and Late Antiquity (AHIS339); and Egypt and the Near East (AHIS399). In addition to a selection of participation components (regular discussion, a bibliographical portfolio, a learning journal, a brief work-in-progress interview and project outline: for details, see below), the unit culminates in a coherent paper, 5,000 words in length, which conforms to the standards of research and writing guidelines expected in peer-reviewed scholarly publications in the fields of ancient world studies. Throughout each Capstone, students collect, assess, analyze and interpret pertinent evidence in the light of current historical thinking

Each unit of study, therefore, includes the following components:

- reviewing the theoretical and methodical framework of the particular degree Major, including integrating fundamental course material in a portfolio;

- $\quad$ reflecting on the development of prescribed graduate capabilities and how these have been achieved within the specified Ancient History Major in seminar discussion and learning journal entries;

- $\quad$ preparing a publication project on a set of pertinent, approved topics.

\subsubsection{Unit rationale}

In sum, both units are designed to provide students with the opportunity to integrate the material covered in the Ancient History degree program, understand how it fits together, and focus on how what they have learned equips them for their next step, whether this be to a next level of study, or into the workforce.

The units allow students to demonstrate their intellectual development of the course of their degree program within either Major. They also reflect on the attainment of graduate capabilities, in particular (but not exclusively) with respect to discipline specific knowledge and skills, critical and analytical thinking, problem solving and research capability, effective communication, the capability of professional and personal judgment, as well as the commitment to continuous learning. They also prepare students for entry into an Honours program.

In both units, the relationship between assessment and unit outcomes is as follows:

[Insert Table 1] 


\subsubsection{1 (A) Unit Outcomes}

At the successful conclusion of this unit it is expected that students will have:

1. acquired knowledge of the historical processes and a knowledge of the fundamental historical developments in Greece and/or Rome and/or Late Antiquity;

2. developed sophisticated research skills;

3. been able to demonstrate their skill in evaluating source material and, in particular, their ability to critically use ancient sources and evaluate modern interpretations of those sources to an advanced level;

4. been able to formulate arguments and articulate ideas to an advanced level;

5. been able to demonstrate a substantial appreciation of the larger issues that engage historians of the ancient world.

\subsubsection{2 (B) Graduate Capabilities}

In addition to the discipline-based learning objectives, all academic programs at Macquarie seek to develop students' generic skills in a range of areas. One of the aims of both Capstone units, therefore, is that students develop their skills in the following:

1. Discipline Specific Knowledge and Skills

2. Critical, Analytical and Integrative Thinking

3. Problem Solving and Research Capability

4. Creative and Innovative

5. Effective Communication

6. Engaged and Ethical Local and Global citizens

7. Socially and Environmentally Active and Responsible

8. Capable of Professional and Personal Judgement and Initiative

9. Commitment to Continuous Learning

\subsubsection{Participation}

Participation in both Capstone units refers to much more than simply being in attendance (whether on campus or in asynchronous discussion/reflection online). Integrated into the Capstone participation process are the elements of feedback, evaluation and action which frame the transformative $\mathrm{L} \& \mathrm{~T}$ experience. There is a relationship between reflection on knowledge and action based on that reflection. For students and teacher, participation involves working together to solve problems. Learning happens because students and teacher have an opportunity to reflect together on their experience with support from others and then convert learning to action. Naturally, students must consistently demonstrate their commitment to the unit by being timely and well-prepared for all campus/online sessions, and completing any required seminar reading and discussion preparation. Of prime importance to the process is active involvement during campus/online discussion, demonstrated by asking and answering questions, participating constructively as required, and showing consideration for their fellow classmates and convenor by relating in a reflexive and collaborative manner.

\subsubsection{Campus Sessions}

A campus session in Week 1 introduces students to the whole-of-program approach encapsulated in both Capstones. Students are asked to consider how their particular Capstone will help them to

- consolidate their learning from the previous units of study, rather than learning new content;

- $\quad$ reflect on the knowledge, skills and capabilities they have acquired and how to demonstrate these in their transition from final year to workplace or further study;

- facilitate development of realistic and feasible topics for the publication project; and

- develop and capture both the learning process during the unit (campus and online seminar discussion; learning journal $\log$ ) and the final learning products (work-in-progress interview and outline; portfolio; publication project).

A second campus session in Week 11 provides a final opportunity for students to make sense of their learning across their whole program of study. Students are asked to reflect on the ways in which they have been able to 
- integrate the material covered in the course;

- understand how it fits together; and

- focus on how their learning equips them for their next step, whether this be to a next level of study, or into the workforce.

There is also an opportunity for students to define more clearly their career path by exploring career planning and management, the value of internships/volunteer/vacation work and the application and interview process.

\subsubsection{Online Seminar Discussion}

Online seminar discussion (Weeks 2-6 and 9-10) explores discrete theoretical approaches and methodological practices met in previous units of study. In the course of each week, students

- consider brief readings and a set of stimulus questions relating to a particular topic;

- $\quad$ provide a brief, integrated response to the stimulus questions in the online forum;

- contribute to discussion generated by individual responses;

- $\quad$ explore issues, ask questions, and share ideas relating to the publication project; and

- $\quad$ collect a representative bibliographical sample of learning materials relating to the topic that proved useful in previous study

This discussion follows the template ennumerated below:

1. Read the extracts listed. These brief readings introduce students to a few of the historical issues relating to the seminar topic for discussion.

2. Discuss the questions asked. Students should take the brief outline provided in this section and the recommended readings as a starting-point only. They are encouraged to ensure that their discussion posts develop further the seminar outline, considering issues which they have encountered personally in their studies at Macquarie (or previous universities).

3. Related MQ Research. As additional supporting material, included in each seminar is an overview (where applicable) of relevant examples of current research undertaken by staff in the Department of Ancient History. In addition to previous learning experiences, this affords students a further opportunity to identify members of academic/research staff best situated to mentor and support individual publication projects.

4. Collect a representative bibliographical sample of learning materials relating to each topic. Students should annotate briefly each item with a view to identifying its historical usefulness.

\subsubsection{Learning Journal}

As part of the blended Capstone experience, students chronicle personal reflections in an individual learning journal. While paper-based learning journals are currently used most often in teaching and training, Capstone students are required to keep an electronic version, different to paper-based journals in that the journal is immediately accessible and public (though in this instance restricted to those enrolled in the unit). Paper-based journals are typically viewed by fellow students or the teacher only at the end of the learning period.

The Ancient History Capstone learning journal is meant to be a reflective, analytical record of each student's learning experiences in the Ancient History program. Students can link their journal record to an individual subject (or subjects) in the program, to a particular topic (or topics) within a subject, and they may wish to reflect about the experience of learning in general.

As the concept of an online learning journal is undoubtedly new, a moderated decision regarding posting rules and journal privacy is made during the introductory on-campus session.

\subsubsection{Portfolio}

Capstone students are required to store discussion responses and contributions, bibliographical materials and learning reflections in a digital portfolio for collecting formative feedback and showcasing learning products for the convenor, markers, peers and potential employers. This is submitted during the final on-campus session.

\subsection{Work-in-progress interview and outline}

This element of the Capstone program is a composite task comprising a brief individual interview on the nature and scope of the student's proposed publication project, and a written outline of the topic, including the parameters of its theoretical foundation and methodological approach. By this stage in the unit, students - in conjunction with 
research mentors (academic/research staff), the Capstone convenor, and their peers - engage in a scaffold of formative research practices: choosing a topic, conducting a literature review, refining ideas, searching for additional information, and drafting a project outline. In the same way as the process of participation, the kind of transformative learning supported by the interview and outline activities weaves together the threads of feedback, evaluation and action, affording students the opportunity to shift who they consider themselves to be (receptive learners only), to recognize themselves as capable of a different order of thought, feeling, and action (active researchers, collaborative producers of knowledge).

\subsubsection{Campus Work-in-Progress Interview}

The work-in-progress interview takes place on-campus during Week 7. On the basis of careful, collaborative preparation, students spend ten minutes discussing their chosen topic for the publication project with a specialist lecturer/researcher of the Ancient History department. The aim of the interview is a focused historical discussion. Ultimately, it will be up to the student to give the member of staff enough information about his or her topic and to demonstrate depth of knowledge and focus of study.

\subsubsection{Work-in-Progress Outline}

Uploaded to the unit assignment dropbox (Week 8), the work-in-progress outline consists of

- a 100-word abstract of the publication topic;

- a 250-word outline of theoretical issues relating to the topic; and

- a 250-word outline of methodological issues relating to the topic.

\subsection{Publication project}

The scope of the publication project is defined by the Department of Ancient History as "the history, art and archaeology of ancient Europe and the Mediterranean world, from prehistoric to late antique times." To that end, the convenor welcomes the submission of manuscripts on any subject within that definition. Unlike the traditional essay assessment task, the publication project is a 5,000 word paper, which each Capstone student generates in relation to the departmental definition above and which springs primarily from the reading and research interests of the learner rather than the unit convenor. In general terms, the project conforms to the standards of research and writing guidelines expected in peer-reviewed scholarly publications in the field of ancient world studies. In collaboration with an academic mentor, the Capstone convenor, and the unit cohort, each student conceptualizes, designs, and develops a project topic (scope, sequence, analytical frame, and interpretative standpoint), producing a coherent paper that reflects enhanced knowledge and substantial understanding of its subject at an advanced undergraduate level and potential for further research. Through self-organized discussion with departmental staff working in areas related to the chosen topic, consultation meetings with the unit convenor, regular dialogue with fellow researchers in the dedicated online publication project forum, and opportunities for reflection in their personal journals, students engage in an intuitive, holistic, and contextually based developmental approach to deep learning linked to the interdependent dynamics of feedback, evaluation, and action.

When preparing publication project manuscripts for submission, students are requested to observe the following:

- The topic and content of the manuscript will conform in all respects to the abstract submitted as the work-in-progress outline.

- The manuscript will be no more than 5,000 words in length.

- $\quad$ Submitted manuscripts will follow the Notes for Contributors guidelines provided in the relevant academic journals (e.g. Journal of Egyptian Archaeology, Journal of Hellenic Studies, Journal of Late Antiquity, Journal of Near Eastern Studies, Journal of Roman Studies).

- Students should retain a copy of their manuscript.

All publication projects are uploaded to the Capstone Unit assignment dropbox by Friday of Week 12.

It should be clear from this outline of the Ancient History Capstone template that both units offer a variety of experiences in synch with the three phases of transformative learning:

1. Critical reflection - online seminar discussion; work-in-progress outline.

2. Reflective discourse - learning journal; work-in-progress interview; Week1/11 campus session.

3. Action - participation; publication project; work- or HDR-pathway.

With this in mind, let us consider briefly how it may be possible to integrate these transformative strategies into a mandatory OUA unit embedded within an exclusively eLT environment. 


\section{The OUA Ancient History Capstone (HST390): transforming eLT in mandatory tertiary education}

The local drivers for implementing transformative eLT should, naturally, be context specific and will vary according to individual departments and faculties. In line with the objectives of Macquarie's Learning and Teaching Plan (LTP), the adaptation of the current blended Capstone Units to a fully-online modality is driven by the desire to develop inclusive online learning experiences, embed quality assurance and enhancement of online unit design and delivery, and increase student expectations - all within a constructive-developmental transformative framework.

As such, the author sees the need for a pedagogical template that

- responds to the increased flexibility offered by transformative eLT practice

- satisfies the greater range of demands for eLT in distance education/OUA contexts

- best incorporates into an online environment research-based approaches to eLT that can be shared and transformed by learners and teachers

Macquarie University adopts a strategic approach to supporting eLT, primarily through institutional Learning and Teaching Centre strategies - exemplified in the Macquarie LTP - as well as its ongoing commitment to providing blended and online education opportunities through departmental programs, the facilities of the Centre for Open Education - integral to the University's provision of many opportunities for lifelong learning including flexibility of access and modes of study, and a primary point of contact between distance education students and the University - and partnership with Open Universities Australia. Through active participatory L \& T, creation of shared experiences and the development of a collective vision, Macquarie University implies transformative L \& T in its LTP as a principle and an enabler guiding the implementation of values that promote and produce the discovery, integration, application and sharing of knowledge.

In line with this vision, and based on current $\mathrm{L} \& \mathrm{~T}$ practice as convenor of the blended units, the author recommends the transition to delivery of a mandatory Ancient History Capstone in online modality as grounded in a five-fold pedagogical framework: envisioning; critical thinking and reflection; participation; partnerships for change; and systemic thinking.

\subsection{Envisioning}

The transformative approach to $\mathrm{L} \& \mathrm{~T}$ occurs when an individual is empowered to reflectively transform their meaning schemes with regard to their beliefs, attitudes, opinions and emotional reactions. Aligned to this view and essential to the implementation of the transition from blended to fully-online Capstone are the articulation and creation of a pedagogical template that fosters a transition from transmissive to transformative approaches in online education (Cranton, 2003; King, 2003).

\subsection{Critical thinking and reflection}

According to the tenets of transformative $\mathrm{L} \& \mathrm{~T}$, learners and teachers need to be reflective, critical thinkers who are open to other perspectives and accepting of new ideas. Dialogue with others is crucial (Reushle, 2005). In particular, the OUA Ancient History Capstone should incorporate metacognitive learning journals. These online learning journals are meant to be a reflective, analytical record of the convenor's and students' learning experiences in the Ancient History program. Convenor and students can link their journal record to an individual subject (or subjects) in the program or a particular topic (or topics) within a subject, and convenor and students can reflect about the experience and process of learning in general. Embedding this interdependent self-reflective element into the online unit should provide the means for students to recognize, evaluate, and integrate their knowledge and understanding of factual information, approaches to research and critical dialogue, and self-directed learning strategies.

\subsection{Participation}

Technological advances and changing societal, economic and political expectations are strongly influencing and encouraging the exploration of how learners and teachers in higher education "can go beyond the acquisition of simple techniques to a deeper reflection on and understanding of their work" (Cranton, 1996, p. vii), suggesting that online settings can provide environments that will support L \& T contexts that are collaborative, interactive and community-based. In keeping with this model, the OUA Ancient History Capstone should foreground those tools which support and foster shared construction of meaning in relation to online collaborative learning experiences. In this regard, the provision of moderated asynchronous seminar discussion forums - keyed to integral methodological and thematic concepts; and supported by a representative inventory of stimulus readings 
(available in a dedicated unit catalogue through the University Library's e-repository - allow informed, interactive exploration of theoretical and practical issues fundamental to the practice and praxis of ancient world studies.

In addition, through scheduled synchronous dialogue, students can engage in a real-time online discussion of their work-in-progress with members of the Department's academic/research staff or the unit convenor. Using a combination of pre-recorded Career Services podcasts, downloadable PowerPoint and Camtasia presentations, and stimulus worksheets, students can learn about and reflect online - in ways similar to the current blended campus session in Week 11 - about their undergraduate OUA Ancient History learning experience and future work/research pathways.

\subsection{Partnerships for change}

Without doubt, online environments can support and promote transformation in L \& T. Bonk (1999, p.410) observes that "online learning offers a chance for learners and teachers to enter into dialogues about authentic problems, collaborate with peers, negotiate meaning, become apprenticed into their field of study, enter a community of experts and peers and generally be assisted in the learning process." When taking into account the literature on transformation theory and the characteristics of transformative learning, there is a strong indication that technology-enhanced educational settings offer an environment conducive to this type of $L \& T$. As should be clear from what has already been said, the author considers the balanced and integrated approach to the incorporation of technologies into the blended $\mathrm{L} \& \mathrm{~T}$ experience readily transferable to a fully online Capstone unit. In addition to the provision of all essential course content materials and assignment submission facilities, the general discussion space delivered through the Moodle 2.1 learning management system should accommodate the various levels of enquiry-based learning - critical personal reflection and interactive dialogue about historical, historiographical, and archaeological theory and practice, as well as individual action relating to submitted, assessible research and potential future directions in work and/or study - built into the proposed HST390 pedagogical framework.

\subsection{Systemic thinking}

In sum, according to this approach, a research-driven framework of pedagogical development and educator participation (in special relation to the department of Ancient History, but more broadly with a view to access across the University), can develop and support a scaffold of transformative skills in eLT. This can be achieved, incorporating Macquarie's LTP goals through tailored support (a departmental seminar dealing with the practical applications of transformative learning theory to eLT); developing partnership with academics (departmental and collegial consultation on the development of HST390); working within departmental, Faculty and Senate L \& T committees; and an awareness-raising event (a dedicated presentation at the annual Macquarie Learning and Teaching Week). As part of this overarching framework, it is hoped that the development and implementation of the fully online OUA Ancient History Capstone unit will generate a portfolio of resources - online guidelines, templates and case studies linked to relevant Capstone L \& T materials and support - susceptible to adaptation more broadly across institutional disciplines and campuses.

\section{First Findings}

Before formulating any thoughts deriving from this study, the author must clarify that it is a study in progress, examining issues that have emerged so far in the research procedure. However, it is possible at this point to acknowledge the potential for mandatory tertiary education of transformative eLT as a means to shift the perspectives of key stakeholders from an instrumental to a more emancipatory conceptualisation of learning. According to Cranton (2006, p.116):

'[...] emancipatory knowledge is fostered through a variety of reformist educator roles. Critical questioning, the presentation of diverse points of view, the examination of existing social norms and the exploration of alternative and radical perspectives helps students become more open in their views and free from the constraints of unquestioned assumptions.'

In conclusion, the application of transformative theory to the development of the OUA Ancient History Capstone highlights several important issues: the fact that this method can serve as an example of alternative use of effective ways of teaching, offering the possibility to enrich traditional teaching models in higher education with experiential practices. It also supports the utility of the fully-online learning environment in education, as well as the educational role of this experience, which can lead to various applications in the future. But above all, it indicates the possibility of obtaining the goal set initially: to 'close the loop' by developing and embedding in the experiences of an online learning community the nexus of reflection-evaluation-action during the $\mathrm{L} \& \mathrm{~T}$ process, especially in the case of the unit in question (HST390). This learning-within-relationship or 
learning-within-community context has the potential for holistic change within individuals and groups participating in online-exclusive environments. The experience of designing, developing, and facilitating the current blended Ancient History Capstone units indicates to the author that the collaborative enquiry of a transformative online learning process with diverse, integrated participatory principles provides a challenging context for critical reflection, dialogue, and other ways of knowing to occur.

\section{References}

Alexander, S., McKenzie, J., \& Geissinger, H. (1998). An Evaluation of Information Technology Project for University Learning. Australian Publishing Service: Canberra.

Baccarini, D. (2010). The implementation of capstone projects. A case study. AUBEA 10, 14/07/2010. Melbourne: Melbourne School of Design.

Bonk, C.J. (1999). Breakout from learner issues. International Journal of Educational Communications. 5(4): 387-410.

Boyer, N. R. (2006). Transformative Learning in Online Settings. Journal of Transformative Education, 4: 335-361. http://dx.doi.org/10.1177/1541344606295318

Burbules, N.C. and Berk, R. (1999) Critical Thinking and Critical Pedagogy: Relations, Differences, and Limits. In Thomas S. Popkewitz and Lynn Fendler, eds.: Critical Theories in Education. New York: Routledge.

Cranton, P. (1994). Understanding and Promoting Transformative Learning: A Guide for Educators of Adults. San Francisco, CA: Jossey-Bass.

Cranton, P. (1996). Professional development as transformative learning. New perspectives for teachers of adults. San Francisco, CA: Jossey-Bass.

Cranton, P. (2003). Finding our way: A guide for adult educators. Toronto: Wall \& Emerson, Inc.

Cranton, P. (2010). Transformative Learning in an Online Environment. International Journal of Adult Vocational Education and Technology, 1,2: 1-9. http://dx.doi.org/10.4018/javet.2010040101

Dewey, J. (1916). Democracy and education. New York: The Free Press.

Dickinson, D. (1992). Lifelong learning for business: A global perspective. Conference on Lifelong Learning for European Business, Oxford University, October 6-7. [Online] Available: www.newhorizons.org/lifelong/workplace/dickinson_oxford.htm (13 February 2011)

Gregson, J.A. (1995). The school-to-work movement and youth apprenticeship in the U.S.: Educational reform and democratic renewal? Journal of Industrial Teacher Education, 32(3):7-29.

Heinecke, W., Dawson, K., \& Willis, J. (2001). Paradigms and frames for R\&D in distance education: Toward collaborative electronic learning. International Journal of Educational Telecommunications, 7(3), 293-322.

Huber, M. T. \& Hutchings, P. (2004). Integrative learning: mapping the terrain. Carnegie Foundation for the Advancement of Teaching, Washington DC. [Online] Available: http://www.carnegiefoundation.org/dynamic/publications/elibrary_pdf_636.pdf (July, 2010).

King, K.P. (2003). Keeping pace with technology: Educational technology that transforms. New Jersey: Hampton Press, Inc.

Koper, R. (2003). Combining reusable learning resources and services with pedagogically purposeful units of learning. In Littlejohn, A. (ed), Reusing Online Resources: A Sustainable Approach to eLearning. London: Kogan Page. 46-59

Learning and Teaching Plan. Planning: Office of the Macquarie University Provost. [Online] Available: http://www.mq.edu.au/provost/planning/landt-plan.html (2 March 2011]

Mayes, T., D. Morrison, H. Mellar, P. Bullen, \& M. Oliver (eds). (2009). Transforming Higher Education through Technology-Enhanced [Online] Aearning. Available: http://www.heacademy.ac.uk/assets/York/documents/ourwork/learningandtech/Transforming.pdf (26 February 2011)

Merriam, S. B., Caffarella, R. S. \& Baumgartner, L. (2007). Learning in adulthood (3rd edition). San Francisco: Jossey-Bass.

Mezirow, J. (2000). Learning as Transformation: Critical Perspectives on a Theory in Progress. San Francisco: Jossey Bass. 
O'Sullivan, E. \& Morrell, A., eds. (2002). Expanding the Boundaries of Transformative Learning: Essays on Theory and Praxis. New York: Palgrave Press.

Raschke, C.A. (2003). The digital revolution and the coming of the postmodern university. London: Routledge. http://dx.doi.org/10.4324/9780203451243

Reushle, S.E. (2005). Inquiry into a transformative approach to professional development for online educators. $\mathrm{PhD}$ thesis, USQ. [Online] Available: http://eprints.usq.edu.au/1494/ (1 March 2011)

Rowles, C. J., Koch, D. C., Hundley, S. P. \& Hamilton, S. J. (2004). Toward a model for capstone experiences: mountaintops, magnets and mandates. Assessment Update, Vol. 16, No. 1, 1-2.

Taylor, E. (1998). The Theory and Practice of Transformative Learning: A Critical Review. Information Series no. 374. Columbus: ERIC Clearinghouse on Adult, Career, and Vocational Education, Center on Education and Training for Employment, College of Education, the Ohio State University.

Taylor, E. (2007, March). An update of transformative learning theory: a critical review of the empirical research (1999-2005). International Journal of Lifelong Education, 26(2), 173-191. http://dx.doi.org/10.1080/02601370701219475

TLC (Teaching \& Learning Centre). (2008). Assessing final year students - capstone units. Macquarie University, Teaching \& Learning Forum: Assessing Learning, Communicating Standards, September.

Table 1. Unit Rationale

\begin{tabular}{|l|l|l|l|l|l|}
\hline TASK & WEIGHT & $\begin{array}{l}\text { DUE } \\
\text { DATE } \\
\text { UNIT } \\
\text { OUTCOMES } \\
\text { (see below A) }\end{array}$ & $\begin{array}{l}\text { LINKED } \\
\text { GRADUATE } \\
\text { CAPABILITIES } \\
\text { (see below B) }\end{array}$ & $\begin{array}{l}\text { BRIEF } \\
\text { DESCRIPTION }\end{array}$ \\
\hline $\begin{array}{l}\text { Participation } \\
\text { (including } \\
\text { Portfolio) }\end{array}$ & $30 \%$ & $\begin{array}{l}\text { Every } \\
\text { seminar }\end{array}$ & $1,2,3,4,5$ & $2,5,6,7,9$ & $\begin{array}{l}\text { Seminar } \\
\text { discussion, } \\
\text { bibliographical } \\
\text { database, learning } \\
\text { journal }\end{array}$ \\
\hline $\begin{array}{l}\text { Work-in-Progress } \\
\text { (WIP) interview } \\
\text { and outline }\end{array}$ & $20 \%$ & Week 8 & $1,2,3,4,5$ & $1,2,3,4,5,8,9$ & $\begin{array}{l}\text { One staff/student } \\
\text { interview; one } \\
\text { project abstract, } \\
\text { not more than 600 } \\
\text { words }\end{array}$ \\
\hline $\begin{array}{l}\text { Publication } \\
\text { Project }\end{array}$ & $50 \%$ & Week 12 & $1,2,3,4,5$ & $1,2,3,4,5,8,9$ & $\begin{array}{l}\text { Publication paper, } \\
\text { not more than } \\
\text { m,000 words }\end{array}$ \\
\hline
\end{tabular}

